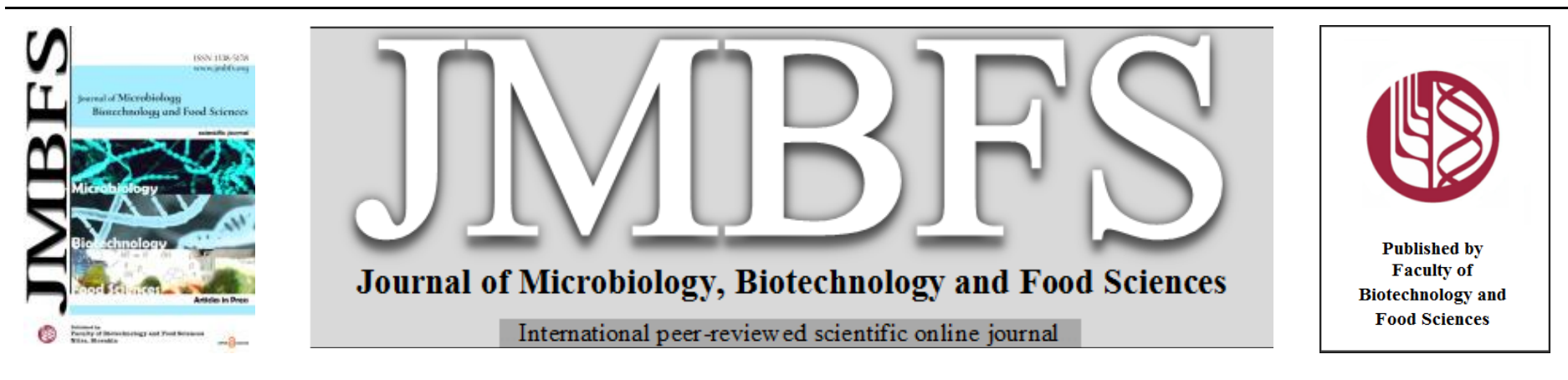

\title{
APPLICATION OF EDIBLE FILM AND COATING BASED ON ALOE VERA GEL FOR PRESERVATION OF PHYSICOCHEMICAL PROPERTIES OF PHYSALIS PERUVIANA L. FRUITS
}

\author{
Marwa R. Ali * and Mohamed E. Abdel-Aziz \\ Address(es): \\ Department of Food Science, Faculty of Agriculture, Cairo University, Giza, 12613, Egypt.
}

*Corresponding author: marwa3mrf@agr.cu.edu.eg

https://doi.org/10.15414/jmbfs.1574

\section{ARTICLE INFO}

Received 21. 4. 2019

Revised 8. 6. 2021

Accepted 29. 6. 2021

Published 1. 12. 2021

Regular article

open 2 access

\begin{abstract}
The calyx removing of Physalis peruviana fruits for production of fresh cut fruit makes its shelf life shorter. So, Aloe vera gel (AV) used as edible film and coating for increasing the fruit shelf life of fresh cut Physalis fruit. The physical parameter of prepared $A V$ films was investigated such as: Thickness, water vapor permeability (WVP) and water solubility. The current study evaluates the effect of $A V$ film and coating for maintain the Physalis peruviana fruits without calyx at $5 \pm 1{ }^{\circ} \mathrm{C}$ and $95 \% \mathrm{RH}$ for 30 days. $A V$ gel film was effective in controlling the fungal decay. which recorded the lowest value (4\%) and reduced deterioration in all other physicochemical properties of Physalis fruit comparing with control. This study showed that the $A V$ gel could be suitable for producing an edible film and coating with good physical characteristics such as low WVP $\left(0.0037 \mathrm{~g} / \mathrm{m}^{2} . \mathrm{h} . \mathrm{mmHg}\right) . A V^{\prime}$ s low WVP appeared to have a great impact on maintaining post-harvest quality especially reducing the percentage of weight loss of coated fruit during storage.
\end{abstract}

Keywords: Aloe Vera gel - Coated fruit - Cold storage - Physalis - postharvest - Water vapor permeability

\section{INTRODUCTION}

Consumers over the world need high-quality food with longer shelf life, without chemical preservatives. So, there are increasing efforts for developing natural antimicrobial and preservative materials. Different preservation techniques used for increasing the shelf life of fruits and vegetables after harvesting: refrigeration and MAP (Athmaselvi et al. 2013). The edible coating could be considered one of the promising technologies that have been used for keeping whole and minimally processed fruit's quality because of their advantages (El-Mogy $\boldsymbol{e t}$ al. 2020). The edible coating has the ability to regulate the transfer of moisture, $\mathrm{O} 2$, $\mathrm{CO} 2$, flavor components in a food order. The edible coating has a similar effect of storage under controlled or MAP for increasing the shelf life of fresh vegetables and fruits (Castillo and Serrano 2005).

Many researches have been shown the usage of an edible coating based on $A V$ gel for table grapes and nectarine (Martinez-Romero et al. 2006 and Ahmed et al.2009), which would be one of the most interesting innovative methods in postharvest treatments and commercial applications.

$A V$ gel mainly composed of polysaccharides, the mucilage plays as a normal barrier to $\mathrm{O} 2$ and moisture, which can increase the rate of food spoilage. Also, it could improve the safety of food. $A V$ gel contains various antibiotic and antifungal components, like quinones and phenolic components (flavonoids) that may be responsible for delaying or inhibition of the growth of microorganisms for food-borne diseases in humans or food spoilage. The $A V$ gel had an excellent effect as an antifungal against Fusarium oxysporum so, it was more effective for controlling fungal decay in cherry tomatoes (Ortega-Toro et al. 2017). AV gel edible coating showed a reduction in firmness loss, moisture loss, respiratory rate, development in maturity, delay browning index, and microorganism growth (Lin and Zhao 2007).

Physalis (Physalis peruviana) is a temperate climacteric fruit originated from America. Physalis fruit is round and small, covered with dark orange calyx and the fruit contain $(150-300)$ seeds which responsible for the acid taste and considers a source of vitamins and flavonols. Physalis (Physalis peruviana L.) is known also as ground-cherry or cape gooseberry. Physalis fruits have an important role in nutrition as a very good base for all dietetic products. Highly valued for its unique flavor and color, several studies reported that physalis fruits are rich in many valuable compounds (Solange $\boldsymbol{e t}$ al. 2016).

The calyx of Physalis fruit works to prolong the post-harvest life up to $67 \%$ when compared to the fruits without calyx and that may be due to the reduction in respiration rate, moisture loss and colour oxidation (Licodiedoff $\boldsymbol{e t}$ al. 2013). According to Bolzan et al. (2011), the Physalis peruviana fruits without calyx could be stored at $2 \pm 1{ }^{\circ} \mathrm{C}$ and $90 \pm 5 \%$ relative humidity up to 58 days, nevertheless, such these conditions are so hard to obtain in the local market. The changes of the fruits depend on many factors such as the presence or absence of the fruit's calyx and storage temperature, which may lead to color change, weight loss \%, softness and the relationship between total soluble solids and total titratable acidity, which responsible for taste and odor. Edible coating defined as a thin layer of edible materials which can apply and form on the surface of the products, maybe an alternate method to minimize changes in Physalis during storage (Licodiedoff et al. 2013).

This study aims to determine the physical characteristics of $A V$ gel film as well as the effect of $A V$ gel as an edible coating or film on minimizing the changes in physicochemical properties of Physalis fruits during cold storage and its role in enhancing the postharvest quality and shelf life of Physalis.

\section{MATERIALS AND METHODS}

\section{MATERIALS}

Aloe Vera leaves and Physalis fresh fruits (Physalis peruviana L.) were purchased from the Faculty of Agriculture - Cairo University experimental station. The other ingredients used to prepare an $A V$ gel film and coating [Corn starch with $12 \%$ moisture content], as a thickening agent and glycerol (98\%)] were purchased from El Nasr Pharmaceutical Co., Egypt.

\section{Preparation of Aloe vera gel}

The $A V$ gel was prepared as described by Elbandy et al. (2014), then the $A V$ gel was filtered for removing the fibers. After that, the gel pasteurized at $100^{\circ} \mathrm{C}$ for 4 minutes then cooled immediately for ambient temperature. After that, the $\mathrm{pH}$ of the $A V$ gel was adjusted by using citric acid solution $\left(4.5 \mathrm{~g} \mathrm{l}^{-1}\right)$ to $\mathrm{pH}(4)$ as recommended by Adetnji et al. (2014). Also, the moisture content of gel was determined according to AOAC, Method 934.06 (1990)

\section{Preparation of Aloe vera gel film and coating}

The Aloe vera gel film or coating solution was formulated as follows: $5 \mathrm{~g}$ of starch (as a thickening agent) was dissolved in $200 \mathrm{ml}$ of distilled water and heated to $95^{\circ} \mathrm{C}$ and mixed thoroughly for 30 minutes until fully homogeneous. Finally, to obtain the volume in $400 \mathrm{ml}$, the $A V$ gel (with moisture content 98.92 $\%$ ) was also incorporated, $1.25 \mathrm{~g}$ of glycerol was added and the solution was held 
hot for $10 \mathrm{~min}$ with mechanical stirring. $100 \mathrm{ml}$ of the film-forming solution was poured and spread evenly over a Teflon plate $(23$ X $22 \mathrm{~cm})$ by stainless steel spreader and dried for further evaluation at room temperature for 24 hours.

\section{Evaluation of the film characteristics}

\section{Film thicknesses}

The film thickness was measured using the micrometer (Model $49-50-02$, Messmer Instrument, Germany). Five measurements were done for each film sample and expressed as $\mu \mathrm{m}$ (Abd El Magied et al. 2009).

\section{Water solubility $(\%)$}

The film scuttle in water was defined as the dry matter content which lost in water after $24 \mathrm{~h}$ of immersion. Two pieces of each film $(1 \times 4 \mathrm{~cm}$ diameter) were cut and weighed. One piece was dried at $105^{\circ} \mathrm{C} / 24 \mathrm{~h}$ for determining the initia dry matter percentage. The other piece was immersed in $50 \mathrm{ml}$ of distilled water for 24 at $25^{\circ} \mathrm{C}$ with sporadic stirring. After that, the pieces of film were removed and dried to constant weight at $105^{\circ} \mathrm{C}$ for $24 \mathrm{~h}$ to determine the weight of dry matter that was dispersed in water. The water solubility $\%$ was determined as the average value of 3 measurements as follows (Sadegh et al. 2012).:

WS $(\%)=[$ Initial dry matter $(\mathrm{g})-$ Final dry matter $(\mathrm{g}) /$ Initial dry matter $(\mathrm{g})] \times 100$

\section{Water vapor permeability (WVP)}

The WVP of $A V$ film was determined according to an ASTM E96-00 procedure (2000). WVP defined as the easing of penetration of moisture and passing through the film hydrophilic portion.

\section{Preparation of Physalis fruits}

Physalis fruits were harvested and stored and $95 \% \mathrm{RH}$, then treated in the next day. 360 fruits with uniform size, physical damage and fungal injury free were used. The calyx of the Physalis fruits were removed then the fruits dipped in chlorinated water then dried using tissue paper. About 120 fruits, randomly distributed in 6 Polypropylene trays $(10 \times 20 \mathrm{~cm})$ with 20 fruits in each tray, for each treatment. Two tray of each treatment was taken for analyses every 6 days until the 30 days of storage period completed. Three treatments conducted, the first treatment was the control (fruit without coating); the second treatment: packaging fruits in $A V$ pouch film and the third treatment: packaging of Physalis fruits in $A V$ pouch film. The third treatment: coating of Physalis fruits with $A V$ coating by dipping into the $A V$ gel solution at $25^{\circ} \mathrm{C}$ for $1 \mathrm{~min}$.

\section{Physico-chemical properties of Physalis fruits}

\section{Decay}

The decay was observed and determined visually as recommended by Shehata $\boldsymbol{e}$ al. (2020) . The decay percent of coated and uncoated Physalis fruit was calculated as follows: [The number of decayed fruits / the number of total fruits] X 100

\section{Weight loss}

The weight loss percentage was calculated by the difference between the initial weight of fruits and the weight of fruits at $0,6,12,18,24$ and $30 \mathrm{~d}$ multiplied by 100 (Awad et al. 2021)

\section{Texture analysis}

Fruits firmness was determined using a texture analyzer as described by Licodiedoff $\boldsymbol{e t} \boldsymbol{a l}$. (2016). Tissue firmness was measured by a texture analyzer (Force Gauge, Model M4-200, USA) with a $50 \mathrm{~kg}$ charge cell. A 2 mm-diameter cylinder pointer was used to analyze perforation. Speeds during the test were respectively, $3.3 \mathrm{~mm} . \mathrm{s}^{-1}$, with a $5 \mathrm{~mm}$ penetration depth for the $30 \mathrm{~s}$. Results were given in $\mathrm{N}$. The results were expressed as the mean of 3 determinations for each treatment.

\section{Total soluble solids content}

TSS $\left(\right.$ Brix $^{\circ}$ ) was determined using a hand refractometer (PAL-3, ATAGO, Japan) according to AOAC method 22.024 (2005).

\section{Browning Index}

The fruit's color was measured using a colorimeter with a Minolta standard (KONICA MINOLTA, Japan) according to the method described by Ganjloo et al., (2009). The color coordinates $a^{*}, b^{*}$ and $L$ were used to calculate the browning index (BI) for the mean of 3 determinations for each treatment according to the method described by Palou et al., (1999).

$$
\begin{aligned}
& \mathrm{BI}=[100(\mathrm{X}-0.31) / 0.172] \\
& \mathrm{X}=\left[\left(a^{*}+1.75 L\right) /\left(5.645 L+a^{*}-3.02 b^{*}\right)\right]
\end{aligned}
$$

pH value

Fruit's pH measured using the digital pH meter (Hanna Instruments, HI 9219) according to Ali et al. (2021).

\section{Titrable acidity \% (TA\%)}

Ten grams of fruit was homogenized and made up to $100 \mathrm{ml}$ with distilled water Then $10 \mathrm{ml}$ of the aliquot was taken and titrated with $0.1 \mathrm{~N} \mathrm{NaOH}$ in present of Phenolphthalein as an indicator in triplicates, from the titer, the Titrable acidity \% was calculated (El - Mogy et al. 2019).

\section{Maturity index (MI)}

The maturity index was calculated according to Catarina et al. (2015) according to the following equation: $\mathrm{MI}=\mathrm{TSS} / \% \mathrm{TA}$

\section{Sensory evaluation}

The consumer panels were used in this study consisted of untrained ten panelists from the staff of Food Science Department, Faculty of Agriculture, Cairo University, Giza, Egypt ( 6 females and 4 males, aged ranged from 25 to 45 y) was used for evaluating sensory quality of Physalis fruit after one day of coating and every 6 days of cold storage. The panelists do not know the experimental approach and the fruits were blind to artificial light at $25^{\circ} \mathrm{C}$. The sensory criteria as color, texture, taste and overall acceptability were carried out based on a ninepoint hedonic scale $(1=$ dislike extremely, $3-4=$ mild dislike, $5=$ reasonable, 6 8 = moderate dislike, 9, like extremely) (Ali and EL Said, 2020).

\section{Statistical analysis}

The results were presented as mean \pm SD. The statistical analysis was performed using One-Way Analysis of Variance (ANOVA). Statistical significance was determined at $(P<0.05)$. Statistical analyses were performed using Co-stat Statistics Software, version 6.4 (Co Hort Software, California, USA).

\section{RESULTS AND DISCUSSION}

\section{Evaluation of the physical characteristics of the film}

\section{Film Thickness}

Results show that $A V$ film was flexible and transparent. The prepared $A V$ film thickness was $65 \mu \mathrm{m}$. The obtained results are in accordance with Ortega-Toro et al. (2017) who reported that starch-based film containing the highest ratio of $A V$ gel (1:1) and plasticized with $0.15 \mathrm{~g}$ glycerol $/ \mathrm{g}$ starch were more homogenous and had a higher gloss and transparency. Also, Pinzon et al. (2018) was shown that the thickness of starch-chitosan-Aloe vera gel film was increased 59.3 to $174.5 \mu \mathrm{m}$ with increasing of $A V$ gel concentration 0 to $500 \mathrm{~g} / \mathrm{l}$ Abugoch et al. (2011) reported that the film thickness depends on the film chemical composition and the film-forming polymer nature. Also, Silva-Weiss et al. (2013) reported that the addition of polyphenolic compounds to starchchitosan films have a crosslinking effect that leads to increase in thickness. A similar result was observed in this study of the $A V$ film solution which contains $5 \mathrm{~g} \mathrm{starch} / 200 \mathrm{ml}$ (as a thickening agent).

\section{Water solubility}

The obtained results were shown that the water solubility (WS) of $A V$ gel was relatively low $(20.65 \%)$ in comparison with other types of polysaccharides polymer films. These can be observed by Sadegh et al. (2012) who noticed that an increment in the portion of $A V$ gel was followed by a decreasing in the water solubility of Aloe vera gel incorporated into Chitosan films. A similar effect was also shown when Pinzon et al. (2018) added $A V$ gel into the chitosan film at 50\% concentration. The edible films with low water vapor permeability usually tend to have low water solubility. Even though it is important to know that the most components of the $A V$ gel are polysaccharides, organic acids and amino acids, which have highwater solubility, so they could easily soluble from the edible films. So, the lower water solubility of $A V$ gel film or how the addition of $A V$ to different types of edible polymers decreasing water solubility still unknown and need more study. 


\section{Water vapor permeability (WVP)}

The film composition hydrophilic-hydrophobic ratio plays an important role in water vapor permeability (WVP). The water vapor permeability of $A V$ gel film at $30{ }^{\circ} \mathrm{C}$ and $0 / 100 \%$ relative humidity was recorded as 0.0037 g.m ${ }^{-2} . h . m m H g$, which is considered relatively low in comparison with other polysaccharides polymer films. So, the $A V$ gel addition could be used for reducing WVP with other types of polysaccharide polymer film as shown in the study of Sadegh et al. (2012) who found that $A V$ gel incorporation had the potential role in enhancing the chitosan film barrier property to water vapor. Ortega-Toro et al. (2017) showed that the addition of $A V$ gel into starch based Film $(1: 1 \mathrm{w} / \mathrm{w})$ reduced water vapor permeability. Also, Pinzon et al. (2018) reported that, the addition of $A V$ gel significantly decreases the water vapor permeability values of the banana starch-chitosan films $2.85 \mathrm{~g} \mathrm{~Pa}^{-1} \mathrm{~s}^{-1} \mathrm{~m}^{-1}$ in films without $A V$ gel to $1.99 \mathrm{~g} \mathrm{~Pa}^{-1} \mathrm{~s}^{-1} \mathrm{~m}^{-1}$. Also, he explained that, with the interaction between the $A V$ gel components and starch-chitosan molecules, reducing the availability of the hydrophilic groups in all of starch and chitosan to interact with water and reducing the film's WVP.

\section{Physico-chemical properties of Physalis fruits}

\section{Decay}

The maximum shelf life of fruits was defined as the time pass away between the application of coatings or films and the visual decay. Results in Table (1) showed that the decay increased significantly during storage. Percentage of decayed fruits was $12 \%$ for the control fruit after 18 days of storage period, however, shelf-life of the $A V$ coated fruit and fruits packed in $A V$ pouch film extended up to 18 days without decay. These results are in accordance with Licodiedoff et al. (2016) who reported that the edible coating of gelatin and calcium chloride markedly reduced the number of decayed fruits and prolonged the storage time up to 17 days without decay. This result is similar to the result of Tripathi et al. (2004), who reported that $A V$ gel was successful in reducing microorganism proliferation in table grape, the effect is higher for yeast and molds than for mesophillic aerobics. Moreover, Brishti et al. (2014) reported that decay percentage reached $27 \%$ of papaya fruits coated with $A V$ gel compared with the control which reached to $100 \%$ at the end of storage. Also, Ortega-Toro et al. (2017) showed that, the starch-based film containing $A V$ gel $(1: 1 \mathrm{w} / \mathrm{w})$ was more effective for controlling fungal decay in cherry tomatoes because he found that, the $A V$ gel has a good effect as antifungal especially for Fusarium oxysporum. The $A V$ film was more effective for reducing the number of infected physalis fruits than the coated fruits. That was explained by Cock, (2008) who identified 26 bioactive phytochemical compounds in $A V$ gel such as anthraquinones, dihydroxyanthraquinones, saponins, acemannan.

Table 1 Effect of Aloe vera gel film and coating on physical properties of Physalis fruit during storage at $5 \pm 1^{\circ} \mathrm{C}$ for 30 days.

\begin{tabular}{|c|c|c|c|c|c|c|c|}
\hline \multirow{2}{*}{$\begin{array}{l}\text { Physical } \\
\text { properties }\end{array}$} & \multirow{2}{*}{ Treatment } & \multicolumn{6}{|c|}{ Storage time at $5{ }^{\circ} \mathrm{C}$ (days) } \\
\hline & & 1 day & 6 days & 12 days & 18 days & 24 days & 30 days \\
\hline \multirow{3}{*}{ 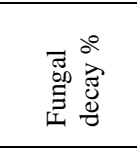 } & Control & $0.00 \pm 0.00$ & $0.00 \pm 0.00$ & $2.00^{\mathrm{a}} \pm 0.71$ & $\begin{array}{c}12.00^{\mathrm{a}} \pm \\
0.71\end{array}$ & $\begin{array}{c}22.00^{\mathrm{a}} \pm \\
1.41\end{array}$ & $43.00^{\mathrm{a}} \pm 2.12$ \\
\hline & Film & $0.00 \pm 0.00$ & $0.00 \pm 0.00$ & $0.00 \pm 0.00$ & $0.00 \pm 0.00$ & $1.00^{\mathrm{c}} \pm 0.71$ & $4.00^{c} \pm 0.70$ \\
\hline & Coating & $0.00 \pm 0.00$ & $0.00 \pm 0.00$ & $0.00 \pm 0.00$ & $3.00^{\mathrm{b}} \pm 0.71$ & $6.00^{b} \pm 1.41$ & $10.00^{\mathrm{b}} \pm 0.71$ \\
\hline \multirow{3}{*}{ 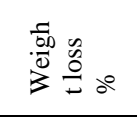 } & Control & $0.00 \pm 0.00$ & $3.89^{\mathrm{a}} \pm 0.00$ & $7.25^{\mathrm{a}} \pm 0.00$ & $12.21^{\mathrm{a}} \pm 0.00$ & $20.69^{\mathrm{a}} \pm 0.01$ & $24.74^{\mathrm{a}} \pm 0.01$ \\
\hline & Film & $0.00 \pm 0.00$ & $3.12^{b} \pm 0.05$ & $6.11^{b} \pm 0.04$ & $10.3^{b} \pm 0.11$ & $15.69^{\mathrm{b}} \pm 0.03$ & $18.05^{\mathrm{b}} \pm 0.06$ \\
\hline & Coating & $0.00 \pm 0.00$ & $3.03^{b} \pm 0.04$ & $5.31^{\mathrm{c}} \pm 0.13$ & $9.08^{c} \pm 0.00$ & $14.09^{\mathrm{c}} \pm 0.01$ & $16.25^{\mathrm{c}} \pm 0.02$ \\
\hline \multirow{3}{*}{ 总 } & Control & $1.49^{a} \pm 0.09$ & $1.11^{\mathrm{b}} \pm 0.00$ & $1.00^{b} \pm 0.16$ & $0.78^{b} \pm 0.16$ & $0.66^{\mathrm{c}} \pm 0.00$ & $0.56^{b} \pm 0.16$ \\
\hline & Film & $1.47^{\mathrm{a}} \pm 0.13$ & $1.45^{\mathrm{a}} \pm 0.16$ & $1.33^{\mathrm{ab}} \pm 0.00$ & $1.22^{\mathrm{a}} \pm 0.16$ & $0.88^{\mathrm{b}} \pm 0.00$ & $0.88^{\mathrm{ab}} \pm 0.00$ \\
\hline & Coating & $1.66^{\mathrm{a}} \pm 0.16$ & $1.56^{\mathrm{a}} \pm 0.00$ & $1.45^{\mathrm{a}} \pm 0.16$ & $1.33^{\mathrm{a}} \pm 0.00$ & $1.11^{\mathrm{a}} \pm 0.00$ & $1.00^{\mathrm{a}} \pm 0.16$ \\
\hline \multirow{3}{*}{$\begin{array}{l}\stackrel{0}{2} \\
\tilde{\omega}\end{array}$} & Control & $8.85^{\mathrm{a}} \pm 0.01$ & $11.00^{\mathrm{a}} \pm 0.00$ & $11.25^{\mathrm{a}} \pm 0.64$ & $12.15^{\mathrm{a}} \pm 0.91$ & $12.9^{\mathrm{a}} \pm 0.26$ & $13.50^{\mathrm{a}} \pm 1.27$ \\
\hline & Film & $8.75^{\mathrm{a}} \pm 0.01$ & $9.65^{\mathrm{ab}} \pm 0.45$ & $11.00^{\mathrm{a}} \pm 0.13$ & $11.25^{\mathrm{ab}} \pm 0.25$ & $11.30^{\mathrm{b}} \pm 0.13$ & $12.20^{\mathrm{b}} \pm 0.01$ \\
\hline & Coating & $8.65^{\mathrm{a}} \pm 0.00$ & $8.90^{\mathrm{b}} \pm 0.00$ & $10.15^{b} \pm 0.36$ & $10.90^{\mathrm{b}} \pm 0.46$ & $10.95^{b} \pm 0.09$ & $12.10^{\mathrm{b}} \pm 0.41$ \\
\hline
\end{tabular}

Means \pm SD $(n=3)$ in the same column followed by the same small letter are not significantly different $(\mathrm{p}<0.05)$.

\section{Weight Loss}

The results of weight loss\% of all samples "Control (Non-coated fruits), coated and packed with the film" are shown in the table (1). Weight loss \% of the fruits was increased with increasing the storage time for all treatments. The results showed a significant increase in weight loss for all treatments through storage time. However, the weight loss of the control sample was significantly higher than the other treatments. On the contrary, the Physalis fruits coated with the $A V$ coating was superior to the other treated samples that had the lowest weight loss $(16.25 \%)$ after 30 days of storage at $5^{\circ} \mathrm{C}$. A similar effect was reported by Mohebbi et al. (2014) who showed that bell pepper coated with $A V$ and gum tragacanth, which recorded the lowest values of weight loss (15.44 and 16.15\%), respectively, meanwhile the weight loss of control reached to $26.80 \%$ at the end of storage period ( 30 days) at $4^{\circ} \mathrm{C}$. Morillon et al. (2002) explained that, the main cause of weight loss of fruit as a result of migration of water from the fruit to the environment during storage. The essential mechanism participating to weight loss is the water evaporation which activated by a flair of water vapor pressure at different sites in bell pepper. The mechanism is based on the coating hygroscopic properties, which has the ability for forming a barrier to wate diffusion between the fruit and environment to avoid its external transference From the previous result we found that the $A V$ film had a lower WVP so, that may be the cause of reducing the weight loss $\%$ of coated or packed physalis fruits.

\section{Firmness}

Results in the table (1) show that the firmness retention of $A V$ coating and pouch film samples were statistically different compared to the control especially after 6 days of storage. The firmness of the control sample gradually decreased during the storage period, where it decreased by $62.4 \%$ after 30 days of storage at $5 \pm 1$ ${ }^{\circ} \mathrm{C}$. At the end of the experiment (30 days), there is no significant difference $(P<0.05)$ between the firmness retention of the $A V$ coating and the $A V$ pouch film of physalis fruits (Table 1). A similar effect was observed by Bolzan et al. (2011) who reported that the firmness of fruits with or without calyx decreased during storage. Also, Mohebbi et al. (2014) reported that using of $A V$ and gum tragacanth as a coating delayed the changes in texture and no excessive softness was noticed in bell peppers after 30 days of storage at $4{ }^{\circ} \mathrm{C}$. The coating may also inhibit the activities of pectin-degrading enzymes closely related to decrease in texture by reducing the metabolic processes rate during senescence, which also participated in the maintenance of fruit hardness (Gwanpua et al. 2014).

\section{Total soluble solids content}

The total soluble solids content $\left(\mathrm{Birix}^{\mathrm{o}}\right.$ ) of different physalis fruits, either coated or pouched and the control sample was presented in Table (1). It could be shown from the results that there were a significant differences between all the tested samples during storage times for the three treatments. As the storage time increased as directly proportional for the entire sample under investigation as shown in Table (1). Usage of $A V$ gel blend coating or film enhance the protection of physalis fruits which could lower the change of TSS\% which recorded $12.10 \%$ and $12.20 \%$ at the end of storage respectively. On the other hand, the control sample recorded the highest percentage of TSS during all storage periods. The TSS\% was $12.15,12.9$ and $13.50 \%$ after 18,24 and 30 days respectively. The obtained results are in accordance with Sharmin et al. (2015), who found that, the lowest TSS\% $7.610 \%$ was found in papaya coated with $A V$ gel $(1.5 \%)$ compared with the control which recorded the highest value of TSS\% $11.47 \%$ after 12 days of storage. Valero1 and Serrano (2013) reported that TSS in grape cultivars increase during storage as a consequence of the advancement of the postharvest ripening process. Such respiration phenomena and variance in TSS content occur together in different strength in accordance with the maturation stage. This may be due to the effect of $A V$ gel coating on the lowering the activity of $\alpha$-galactosidase, polygalacturonase and pectin methylesterase (Nunan $\boldsymbol{e t}$ al. 1998). 


\section{Browning index $(\mathrm{BI})$}

Figure (1) showed the result of the BI of Physalis fruits with $A V$ edible film and coating stored at $5 \pm 1^{\circ} \mathrm{C}$ for 30 days. No significant difference was observed in all treatments for BI of Physalis fruit after 30 days of storage. All treatments up to 12 days of storage were in significantly $(P<0.05)$. The $A V$ gel (film or coating) could delay the increase in BI during storage which reached to 126.11 and 131.03, respectively compared with the control which reached to 207.72 at the end of storage. These results are in accordance with Supapvanich et al. (2016) who reported that, the ability of fresh $A V$ gel for maintaining $L^{*}$ and delaying the increase in browning index of apple slices after storage for 6 days at $4^{\circ} \mathrm{C}$ According to previous articles, $A V$ gel edible coating was shown a reduction in firmness loss, moisture loss, respiratory rate, development in maturity, delay browning index, and microorganism growth in fruits such as table grapes (Martinez-Romero et al. 2006) and nectarines (Ahmed et al. 2009) also, they suggested that the $A V$ gel coating or film created a modified atmosphere around the fruits which reduced the production rate of ethylene, which, delay ripening, degradation of chlorophyll, accumulation of anthocyanin and synthesis of carotenoid and that lower fruits color surface changes.

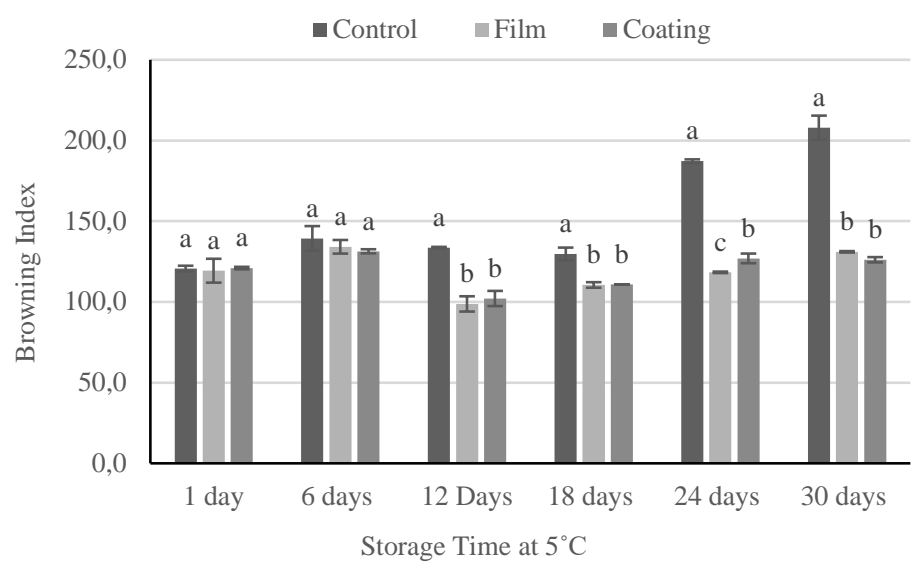

Figure 1 Effect of Aloe vera gel film and coating on browning index (BI) of Physalis fruit during storage at $5 \pm 1^{\circ} \mathrm{C}$ for 30 days.

Means followed by different letters are significantly different $(\mathrm{P}<0.05 \%)$.

\section{Titratable acidity}

The total titratable acidity (TA) was calculated as citric acid, which is the dominant acid in physalis fruits. Results in Fig. (2) show the changes of titratable acidity (TA\%) of different tested physalis fruits, either coated or packed with the $A V$ as well as the control sample through different storage times (up to 30 days) at $5^{\circ} \mathrm{C}$. A significant difference could be shown among all the tested samples. Data in Fig (2) show that the titratable acidity for all the samples recorded the highest percentage of the initial storage (after one-day storage). However, as the storage time (days) increased, the titratable acidity $(\%)$ decreased. The lower level of titratable acidity could be noticed in the control sample at the end of storage time, which recorded $2.10 \%$. Meanwhile, the coated or packed samples with $A V$ had almost the same percentage of titratable acidity after 30 days of storage 2.27 and $2.30 \%$, respectively. Also, Sharmin et al. (2015), reported that papaya fruits coated $A V$ gel $(0.5 \%)$ recorded the minimum change of titrable acidity $(0.39 \%)$. This retention of TA content by coated papaya was due to the protective effect of $A V$ coating as a barrier to $\mathrm{O}_{2}$ from the surrounding atmosphere and reduction of respiration (Srinu et al. 2012). Andrea et al. (2017) who found that the decrease in titratable acidity of Gooseberry fruits coated with calcium chloride demonstrates maturity development. They also noticed that the TA was decreased as storage time increased for all the tested samples. So, the application of $A V$ film and coating support the postharvest life of Physalis fruits and prolong the shelf life due to a higher fruits content of acid. Therefore Valero1 and Serrano (2013) reported that mature fruits do not taste acidic because of the large amounts of accumulated sugars and the decrease of total acidity that usually occur during ripening.

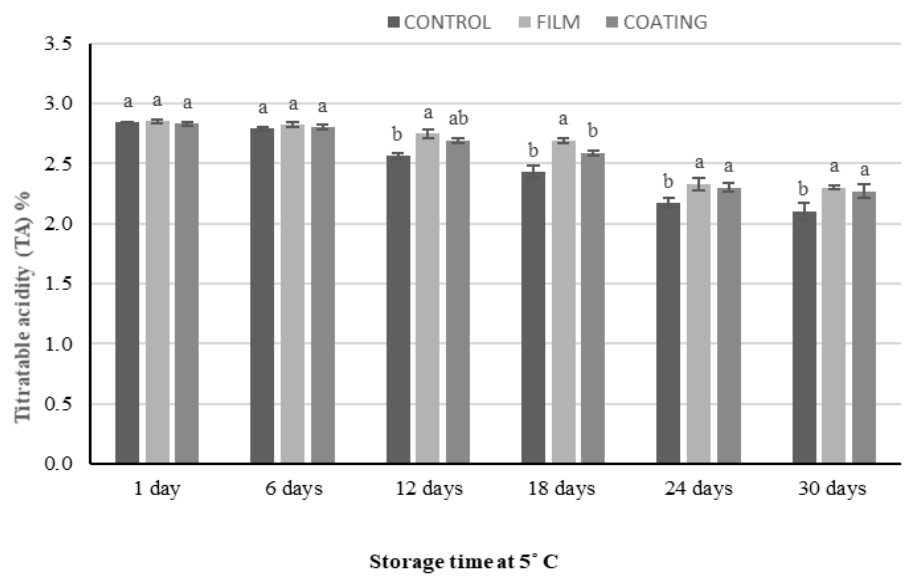

Figure 2 Effect of Aloe vera gel film and coating on titratable acidity \% of Physalis fruit during storage at $5 \pm 1^{\circ} \mathrm{C}$ for 30 days.

Means followed by different letters are significantly different $(\mathrm{P}<0.05 \%)$.

\section{pH value}

Figure (3) show the $\mathrm{pH}$ values for Physalis fruits stored at $5 \pm 1{ }^{\circ} \mathrm{C}$ for 30 days for different treatments. The $\mathrm{pH}$ values of different tested Physalis fruits, either coated or packed with $A V$ as well as the control sample through different storage times (up to 30 days) at $5 \pm 1{ }^{\circ} \mathrm{C}$. A significant difference could be shown among all the tested samples. Data in Fig (3) show that the $\mathrm{pH}$ values for all the samples recorded the lowest percentage of the initial storage (after one-day storage). However, as the storage time (days) increased, the $\mathrm{pH}$ values increased. The highest values of $\mathrm{pH}$ could be noticed in the control sample at the end of storage time, which recorded 3.99. Meanwhile, the packed fruits with $A V$ had the lowest $\mathrm{pH}$ value (2.77) after 30 days of storage followed by the coated fruits which recorded (3.87). The obtained results in accordance with Athmaselvi et al. (2013) showed that the $\mathrm{pH}$ value of uncoated tomato after 20 days of storage was 4.15, whereas for tomato fruits coated with $A V$ gel was 4.07 . It may be suggested that the increase in $\mathrm{pH}$ values may be linked with the maturation process. The respiration process of fruits corresponds to the oxidation reactions of organic acids and carbohydrates which are converted to water and $\mathrm{CO}_{2}$, and producing chemical energy during storage Athmaselvi et al. (2013).

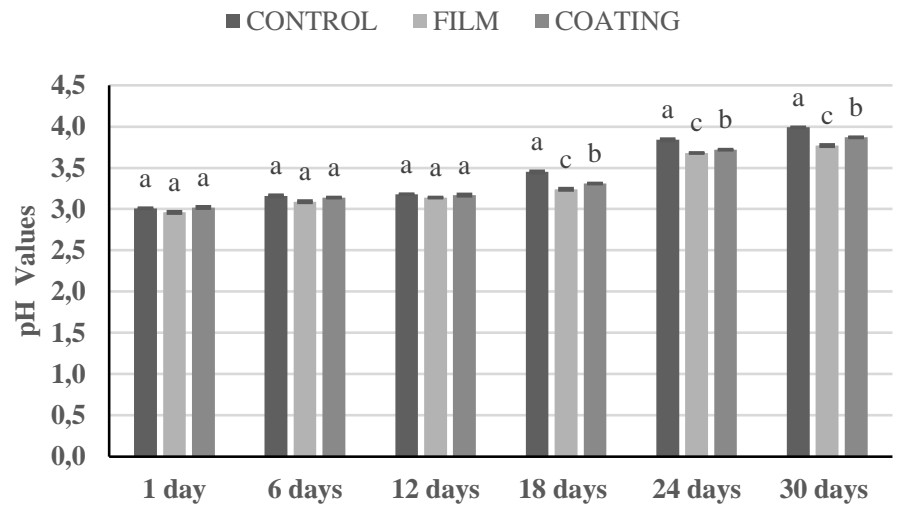

Storage perod at $5^{\circ} \mathrm{C}$

Figure 3 Effect of Aloe vera gel film and coating on $\mathrm{pH}$ of Physalis fruit during storage at $5 \pm 1^{\circ} \mathrm{C}$ for 30 days.

Means followed by different letters are significantly different $(\mathrm{P}<0.05 \%)$.

\section{Maturity index}

Maturity index showed significant change during cold storage between control and other treatments meanwhile, no differences were observed between film and coating of $A V$ gel (Fig 4). The obtained results were shown a higher maturity index of near 12 for control sample at the end of the storage period (30 days) comparing with other treatment of $A V$ which recorded lower value near to 10 . These results are in according with Catarina et al. (2015) Who observed lower maturity index (near to 9) in gooseberry fruits coated with Alginate and stored at $2^{\circ} \mathrm{C}$ for 21 days. The results showed the ability of $A V$ gel coat or film for significantly decreasing the metabolism activity of fruit during the storage at $5^{\circ} \mathrm{C}$ without significant changes of the fruit organoleptic quality. 
-Control $n$ Film $n$ Coating

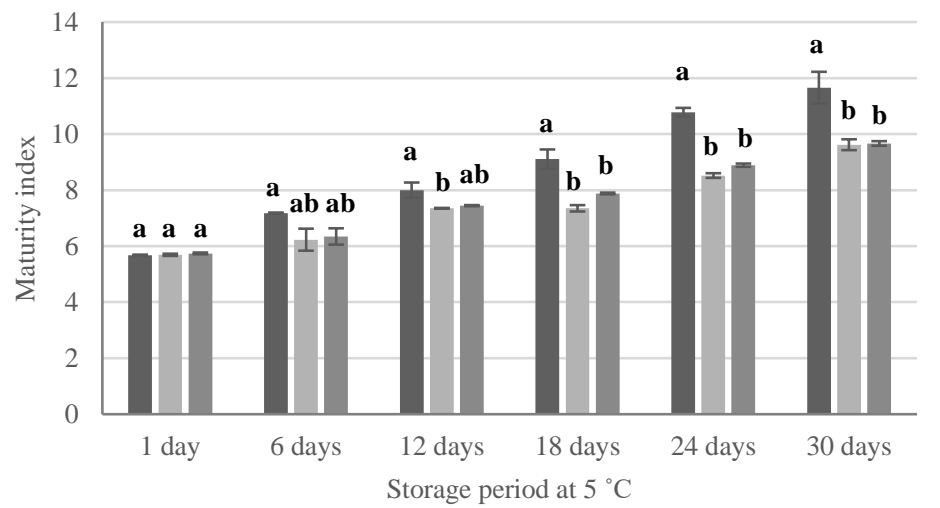

Figure 4 Effect of Aloe vera gel film and coating on maturity index of Physalis fruit during storage at $5 \pm 1^{\circ} \mathrm{C}$ for 30 days.

Means followed by different letters are significantly different $(\mathrm{P}<0.05 \%)$.

\section{Sensory evaluation of Physalis fruits}

The results of the sensory evaluation of the three treatments for Physalis fruits illustrated in Table $(2)$ showed significant differences $(P<0.05)$. The coated fruits, as well as the fruits packed into the $A V$ gel film, were superior compare to the control sample for color, taste, texture and overall acceptability up to 12 days of storage period that affected by the surrounded environmental conditions. Control Physalis fruits showed a great decrease in all the tested parameters throughout the storage times meanwhile, the coated or packed fruits looked shiny, attractive and did not produce an unacceptable odor or off-flavor. These results in accordance with Martinez-Romero et al. (2006) who reported that the cherry tomato coated with $A V$ gel and stored for 16 days at $1^{\circ} \mathrm{C}$ had a good appearance and acceptable flavor than the control which, showed several symptoms of dehydration and color oxidation.

Table 2 Sensory evaluation for Physalis fruits coated and packed in Aloe Vera gel edible film as well as control stored at $5 \pm 1^{\circ} \mathrm{C}$ for 30 days.

\begin{tabular}{|c|c|c|c|c|c|c|c|}
\hline \multirow{2}{*}{ Parameter } & \multirow{2}{*}{ Treatment } & \multicolumn{6}{|c|}{ Storage time at $5^{\circ} \mathrm{C}$} \\
\hline & & 1 day & 6 days & 12 days & 18 days & 24 days & 30 days \\
\hline \multirow{3}{*}{$\frac{\overline{0}}{0}$} & Control & $9.0^{\mathrm{a}} \pm 0.0$ & $8.0^{b} \pm 0.0$ & $8.0^{a} \pm 0.0$ & $8.0^{\mathrm{a}} \pm 0.0$ & $6.5^{\mathrm{a}} \pm 0.7$ & $5.8^{b} \pm 0.4$ \\
\hline & Film & $9.0^{\mathrm{a}} \pm 0.0$ & $9.0^{\mathrm{a}} \pm 0.0$ & $8.5^{\mathrm{a}} \pm 0.0$ & $8.5^{\mathrm{a}} \pm 0.7$ & $7.6^{\mathrm{a}} \pm 0.4$ & $7.3^{\mathrm{a}} \pm 0.0$ \\
\hline & Coating & $9.0^{\mathrm{a}} \pm 0.0$ & $9.0^{\mathrm{a}} \pm 0.0$ & $9.0^{\mathrm{a}} \pm 0.0$ & $8.5^{\mathrm{a}} \pm 0.5$ & $7.7^{\mathrm{a}} \pm 0.3$ & $7.0^{\mathrm{a}} \pm 0.3$ \\
\hline \multirow{3}{*}{ 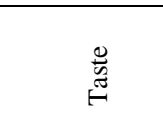 } & Control & $9.0^{\mathrm{a}} \pm 0.0$ & $8.0^{\mathrm{a}} \pm 0.0$ & $8.0^{a} \pm 0.0$ & $7.0^{\mathrm{b}} \pm 0.0$ & $6.6^{b} \pm 0.7$ & $4.7^{b} \pm 0.4$ \\
\hline & Film & $9.0^{\mathrm{a}} \pm 0.0$ & $8.5^{\mathrm{a}} \pm 0.7$ & $8.5^{\mathrm{a}} \pm 0.7$ & $8.5^{\mathrm{a}} \pm 0.0$ & $7.8^{\mathrm{a}} \pm 0.4$ & $7.0^{\mathrm{a}} \pm 0.4$ \\
\hline & Coating & $9.0^{\mathrm{a}} \pm 0.0$ & $8.5^{\mathrm{a}} \pm 0.7$ & $8.5^{\mathrm{a}} \pm 0.7$ & $8.0^{\mathrm{ab}} \pm 0.7$ & $7.3^{a b} \pm 0.4$ & $7.3^{\mathrm{a}} \pm 0.0$ \\
\hline \multirow{3}{*}{ 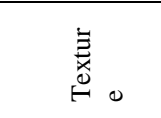 } & Control & $9.0^{\mathrm{a}} \pm 0.0$ & $8.0^{\mathrm{a}} \pm 0.0$ & $7.5^{a} \pm 0.7$ & $6.3^{\mathrm{b}} \pm 0.4$ & $5.3^{b} \pm 0.3$ & $5.0^{b} \pm 0.0$ \\
\hline & Film & $9.0^{\mathrm{a}} \pm 0.0$ & $8.5^{\mathrm{a}} \pm 0.0$ & $8.8^{\mathrm{a}} \pm 0.7$ & $7.8^{\mathrm{a}} \pm 0.4$ & $7.4^{\mathrm{a}} \pm 0.1$ & $7.3^{\mathrm{a}} \pm 0.0$ \\
\hline & Coating & $9.0^{\mathrm{a}} \pm 0.0$ & $9.0^{\mathrm{a}} \pm 0.7$ & $8.5^{\mathrm{a}} \pm 0.4$ & $7.8^{\mathrm{a}} \pm 0.4$ & $7.6^{\mathrm{a}} \pm 0.2$ & $7.5^{\mathrm{a}} \pm 0.4$ \\
\hline \multirow{3}{*}{ 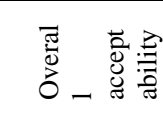 } & Control & $9.0^{\mathrm{a}} \pm 0.0$ & $9.0^{\mathrm{a}} \pm 0.0$ & $8.0^{\mathrm{b}} \pm 0.0$ & $7.0^{\mathrm{b}} \pm 0.0$ & $6.3^{b} \pm 0.4$ & $4.5^{b} \pm 0.0$ \\
\hline & Film & $9.0^{\mathrm{a}} \pm 0.0$ & $9.0^{\mathrm{a}} \pm 0.0$ & $9.0^{\mathrm{a}} \pm 0.0$ & $8.3^{\mathrm{ab}} \pm 0.7$ & $7.8^{\mathrm{a}} \pm 0.4$ & $7.5^{\mathrm{a}} \pm 0.4$ \\
\hline & Coating & $9.0^{\mathrm{a}} \pm 0.0$ & $9.0^{\mathrm{a}} \pm 0.0$ & $9.0^{\mathrm{a}} \pm 0.0$ & $8.5^{\mathrm{a}} \pm 0.4$ & $8.3^{\mathrm{a}} \pm 0.4$ & $7.8^{\mathrm{a}} \pm 0.0$ \\
\hline
\end{tabular}

\section{CONCLUSIONS}

The results of this study showed that the $A V$ gel solution is suitable for producing an edible film and coating with good physical characteristics. Also, the curren study showed the ability of Aloe Vera gel edible film and coating for prolonging the shelf life and maintain of the quality parameter of Physalis fruits. Edible film and coating showed a decreasing in fungal decay \% comparing to control fruits. Moreover, Aloe Vera gel film and coating conserve the regarding of the physicochemical parameters for 30 days of storage at $5^{\circ} \mathrm{C}$ which, significantly reduced weight loss, firmness and retarded the changes on the color of physalis fruits.

\section{CONFLICT OF INTEREST: Authors have no conflict of interest to declare.}

\section{REFERENCES}

Abd El Magied, M. M., Salama, N. A., Nagy, K S. and Ali, M. R. (2009) Packaging of refrigerated strawberry (Fragaria ananassa) using prepared edible wheat gluten films and coatings. Bull. Fac. Agric., Cairo Univ., 60 (2), 177 -168. Abugoch, L. E., Tapia, C., Villamán, M. C., Yazdani-Pedram, M. and Díaz Dosque, M. (2011). Characterization of quinoa protein chitosan blend edible films. Food $\quad$ Hydrocolloids. $\quad 25 \quad$ (5), $\quad$ 1-8 https://doi.org/10.1016/j.foodhyd.2010.08.008

Adetnji, C.O., Fadiji, A.E.1. and Aboeji, O.O. (2014). Effect of chitosan coating combined Aloe Vera gel on cucumber (Cucumis Sativa L.) post-harvest quality during ambient storage. Journal of Emerging Trends in Engineering and Applied Sciences (JETEAS). 5(6), 391-397.

Ahmed, M. J., Singh, Z., and Khan, A.S. (2009). Postharvest Aloe vera gelcoating modulates fruit ripening and quality of 'Arctic Snow' nectarine kept in ambient and cold storage. International Journal of Food Science and Technology. 44 (5), 1024-1033. https://doi.org/10.1111/j.1365-2621.2008.01873.x

Ali, M. R., \& EL Said, R. M. (2020). Assessment of the potential of Arabic gum as an antimicrobial and antioxidant agent in developing vegan "egg-free" $\begin{array}{llll}\text { mayonnaise. Journal of Food Safety. 40(2), e12771. } & \end{array}$ https://doi.org/10.1111/jfs.12771

Ali, M. R, Mohamed, R. M. and Abedelmaksoud, T.G.(2021). Functional strawberry and red beetroot jelly candies rich in fibers and phenolic compounds. Food systems. 4(2), 12-18. https://doi.org/10.21323/2618-9771-2021-4-2-12-18
Andrea, J.R., Elberth, H.P. and Javier, G.A. (2017). Effect of calcium chloride and refrigeration on the quality and organoleptic characteristics of cape gooseberry (Physalis peruviana L.). Acta Agronomica., 66 (1), 15-20 DOI: https://doi.org/10.15446/acag.v66n1.50610

Association of Official Analytical Chemistry. (AOAC). (1990). Official Methods of Analysis of the Association of the Official Analytical Chemists. $15^{\text {th }}$ ed Arlington.

Association of Official Analytical Chemistry. (AOAC). (2005). Official Methods of Analysis of AOAC international. $17^{\text {th }}$ ed. Gaithersburg, MD, USA.

ASTM. (2000). Standard test methods for water vapor transmission of materials, method E 96-00. Philadelphia, PA: American Society for Testing and Materials (2000).

Athmaselvi, K.A., Sumitha, P. and Revathy, B. (2013). Development of Aloe vera based edible coating for tomato. Intonational Agrophysics. 27, 369-375 https://doi.org/10.2478/intag-2013-0006

Awad, A. H. R., Parmar, A., Ali, M. R., El-Mogy, M. M. and Abdelgawad, K. F. (2021). Extending the Shelf-Life of Fresh-Cut Green Bean Pods by Ethanol, Ascorbic Acid, and Essential Oils. Foods. 10, 1103. https://doi.org/10.3390/foods10051103

Bolzan, R. P., Cuquel, F .L. and Lavoranti, O. J. (2011). Cold storage of cape gooseberry. Revista Brasileira de Fruticultura. 33(1), 577-583.

Brishti, F.H., Misir, J. and Sarker, A. (2013). Effect of Biopreservatives on storage life of Papaya fruit (Carica Papaya L.), International Journal of Food Studies. 2 (1), 126-136. https://doi.org/10.7455/ijfs.v2i1.149

Castillo S. and Serrano M. (2005). Novel edible coating based on Aloe vera gel to maintain table grape quality and safety. Journal of Agriculture and Food Chemistry. 53, 7807-7813. https://doi.org/10.1021/jf050962v

Catarina, P. C., Debora, V., Diego, A. Moreno, M. Serrano, M. and Daniel, V. (2015). Alginate edible coating and cold storage for improving the physicochemical quality of cape gooseberry (Physalis Peruviana L.). Food Science and Nutrition. 1(1), 1-7. https://doi.org/10.24966/fsn-1076/100002

Cock, I. E. (2008). Antimicrobial Activity of Aloe barbadensis Miller Leaf Ge Components. The Internet Journal of Microbiology. 4(2), 1-12. https://doi.org/10.5580/15bc

Elbandy, M. A., Abed, S. M., Gad, S. S. A and Abdel-Fadeel, M. G. (2014). Aloe vera gel as a functional ingredient and natural preservative in mango nectar. World Journal of Dairy and Food Sciences. 9 (2): 191-203.

El-Mogy, M. M., Ali, M. R., Darwish, O.S. and Rogers, H. J. (2019). Impact of salicylic acid, abscisic acid, and methyl jasmonate on postharvest quality and 
bioactive compounds of cultivated strawberry fruit. Journal of Berry Resaarch.9, 333-34. https://doi.org/10.3233/JBR-180349

El-Mogy, M. M., Parmar, A., Ali, M. R., Abdel-Aziz, M. E. and Abdeldaym, E. A. (2020). Improving postharvest storage of fresh artichoke bottoms by an edible coating of Cordia myxa gum. Postharvest Biology and Technology 163: 111143 https://doi.org/10.1016/j.postharvbio.2020.111143

Ganjloo, A. Rahman, J. Bakar, A. Osman, A. and Bimakr, M. (2009). Modelling the kinetics of peroxidase inactivation and color changes of seedless guava (Psidium guajava L.) during thermal treatments. World of Applied Science Journal. 7: 105- 112.

Gwanpua, S.G., Buggenhout, S.V., Verlinden, B.E., Geeraerd. A. and et al., (2014). Pectin modifications and the role of pectin-degrading enzymes during postharvest softening of Jonagold apples. Food Chemistry. 158:283-291. DOI: 10.1016/j.foodchem.2014.02.138

Garzón-Acosta C. P., Villarreal-Garzón, D. M., Fischer, G., Herrera, A. O. and Sanjuanelo, D. W. (2014). Deficiencies of phosphorus, calcium and magnesium affect thepostharvest quality of Cape gooseberry (Physalis peruviana L.) Fruits. $\begin{array}{llll}\text { Acta-Horticulture } & \text { (ISHS) } & \text { 83-88. }\end{array}$ https://doi.org/10.17660/actahortic.2014.1016.9

Licodiedoff, S., Koslowski, L. A. D. and Ribani, R. H. (2013). Flavonols and antioxidant activity of Physalis peruviana L. fruit at two maturity stages. Acto

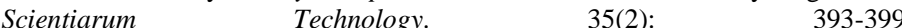
https://doi.org/10.4025/actascitechnol.v35i2.13265

Licodiedoff, S., Koslowski, L. A. D., Scartazzini, L., Monteiro, A. R., Ninow, J. L. and Borges, C. D. (2016). Conservation of physalis by edible coating of gelatin and calcium chloride. International Food Research Journal, 23(4): 16291634.

Lin, D. and Zhao, Y. (2007). Innovations in the development and application of edible coatings for fresh and minimally processed fruits and vegetables comprehensive review. Comprehensive Reviews in Food Science and Food Safety. 6, 60-71. https://doi.org/10.1111/j.1541-4337.2007.00018.x

Martinez-Romero, D, Alburquerque, N., Valverde, J., Guillen, F., Castillo, S., Valero, D. and Serrano, M. (2006). Postharvest sweet cherry quality and safety maintenance by Aloe vera treatment: A new edible coating. Postharvest Biology $\begin{array}{llll}\text { and } & \text { Technology. } & 39 & \text { (1). }\end{array}$ https://doi.org/10.1016/i.postharvbio.2005.09.006

Mohebbi, M., Hasanpour, N., Ansarifar, E. and Amiryousefi, M. R. (2014) Physicochemical properties of bell pepper and kinetics of its color change influenced by Aloe vera and gum tragacanth coatings during storage at different temperatures. Journal of Food Processing and Preservation 38, 684-693. https://doi.org/10.1111/jfpp.12018

Morillon, V., Debeaufort, F., Blond, G., Capelle, M. and Voilley, A.(2002). Factors affecting the moisture permeability of lipid-based edible films: Critica Reviews in Food Science and Nutrition. 42, 67-89. https://doi.org/10.1080/10408690290825466

Nunan, K. J., Sims, I. M., Bacic, A., Robinson, S. P. and Fincher, G. B. (1998) Changes in cell wall composition during ripening of grape berries. Plant Physiology. 118(3): 783-792. https://doi.org/10.26686/wgtn.12597848.v1

Ortega-Toro, R., Collazo-Bigliardi, S., Roselló, J., Santamarina, P. and Chiralt, A. (2017). Antifungal starch-based edible films containing Aloe vera. Food Hydrocolloids. 72, 1-10. https://doi.org/10.1016/j.foodhyd.2017.05.023

Palou, E., Lopez-Malo, A., Barbosa-Cnovas, G. V., Welti-Chanes, J. and Swanson, B. G. (1999). Polyphenoloxidase activity and color of blanched and high hydrostatic pressure treated banana puree. Journal of Food Science. 64(1), 42-45. https://doi.org/10.1111/j.1365-2621.1999.tb09857.x

Pinzon, M. I, Garcia, M. R. and Villa, C. C. (2018). The influence of Aloe vera gel incorporation on the physicochemical and mechanical properties of banana starch-chitosan edible films. Journal of The Science of Food and Agriculture. 1-8. https://doi.org/10.1002/jsfa.8915.

Pizato, S., Cortez-Vega, W. R., Souza, J. T. A., Prentice- Hernández, C. and Borges, C. D. (2013). Effects of different edible coatings in physical, chemical and microbiological characteristics of minimally processed peaches (Prunuspersical batsch). Journal of Food Safety. 33(1): 30-39. https://doi.org/10.1111/jfs.12020

Sadegh, K., Mohammad, H., Zohreh, H., and Niloofar, B. (2012). Mechanical, physicochemical and color properties of chitosan based-films as a function of Aloe vera gel incorporation. Carbohydrate Polymers. 87(3), 2058-2062. https://doi.org/10.1016/j.carbpol.2011.10.020

Sharmin, M. R., Islam, M. N. and Alim, M. A. (2015). Shelf-life enhancement of papaya with Aloe vera gel coating at ambient temperature. Journal of the Bangladesh Agricultural University. 13(1), 131-136 https://doi.org/10.3329/jbau.v13i1.28729

Shehata, S. A., Abdeldaym, E. A., Ali, M. R., Mohamed, R. M., Bob, R. I., AbdelGawad, K. F. (2020). Effect of Some Citrus Essential Oils on Post-Harvest Shelf Life and Physicochemical Quality of Strawberries during Cold Storage. Agronomy. 10: 1466. doi:10.3390/agronomy10101466

Silva-Weiss, A., Bifani, V., Ihl, M., Sobral, P. J. A and Gomez-Guillén, M. C. (2013). Structural properties of films and rheology of film-forming solutions based on chitosan and chitosan-starch blend enriched with murta leaf extract
Food

Hydrocolloids.

$31(2)$

$458-466$

https://doi.org/10.1016/j.foodhyd.2012.11.028

Solange, F. O., Fernando, J. A. G., Paula, M. R. C. and Raquel, P. F. G. (2016) Physical properties of Physalis peruviana L. Open Agriculture. 1(1), 55-59. https://doi.org/10.1515/opag-2016-0007

Srinu, B., Vikram, K. B., Rao, L. V., Kalakumar, B., Rao, T. M. and Reddy, A G. (2012). Screening of antimicrobial activity of Withania somnifera and Aloe vera plant extracts against food borne pathogens. Journal of Chemistry and Pharmaceutical Research. 4(11): 4800-4803.

Tripathi, P. and Dubey, N. (2004). Exploitation of natural products as an alternative strategy to control postharvest fungal rotting of fruit and vegetables. $\begin{array}{lllll}\text { Postharvest Biology and Technology. } 32 & \text { (3), 235-245. }\end{array}$ https://doi.org/10.1016/j.postharvbio.2003.11.005

Valero, D. and Serrano, M. (2013). Growth and ripening stage at harvest modulates postharvest quality and bioactive compounds with antioxidant activity. Stewart Postharvest Review. 9 (3), 1-8. https://doi.org/10.2212/spr.2013.3.7 